\title{
Impact of medium-chain monoglycerides on intestinal colonisation by Vibrio cholerae or enterotoxigenic Escherichia coli
}

\author{
BRYON W. PETSCHOW, ROSANNE P. BATEMA, ROBERT D. TALBOTT and LORNA L. FORD \\ Bristol-Myers Squibb Co., Mead Johnson Research Centre, 2400 W. Lloyd Expressway, Evansville, IN 47721, \\ USA
}

\begin{abstract}
Although a number of studies have shown that various free fatty acids (FFAs) and monoacylglycerides (MGs) have bactericidal properties in vitro, the role of these compounds in vivo has not been determined. This study evaluated the antibacterial properties of medium-chain MGs and FFAs for different bacterial enteropathogens with an in-vitro bacterial killing assay and an in-vivo model of intestinal colonisation. Incubation of test bacteria with medium-chain MGs for $4 \mathrm{~h}$ led to 100-10000-fold reductions in numbers of viable cells of Vibrio cholerae, Salmonella typhi, Shigella sonnei and enterotoxigenic Escherichia coli (ETEC). Lauric acid was the only mediumchain FFA to show comparable in-vitro bactericidal activity. The ability of dietary MGs to reduce or eliminate bacterial colonisation of the intestinal tract was evaluated in mice that were predisposed to bacterial colonisation by treatment with streptomycin $\left(\mathrm{STR}^{+}\right)$. Mice were treated with streptomycin, challenged intragastrically with $V$. cholerae or ETEC, and given monocaprin (C10:0 MG) either concurrently or as part of the daily diet. Control mice given $\mathrm{STR}^{+}$without MGs and challenged with $V$. cholerae or ETEC showed high numbers of challenged bacteria in gastrointestinal contents by $1 \mathrm{~h}$ after administration. Concurrent administration of $V$. cholerae and C10:0 MG $(2.5 \mathrm{mg} / \mathrm{ml})$ caused $>1000$-fold reduction in numbers of $V$ cholerae recovered from the gastrointestinal tracts of $\mathrm{STR}^{+}$mice. Concurrent administration of C10:0 MG with ETEC did not cause a reduction in the number of viable ETEC present in the intestinal tract of $\mathrm{STR}^{+}$mice. Administration of C10:0 MG in the diet had no effect on the number of viable $V$. cholerae or ETEC associated with caecal or ileal tissue of STR ${ }^{+}$ mice when C10:0 MG in the diet was started 1 day before, the same day, or 2 days after bacterial challenge. Collectively, these results suggested that dietary MGs may prevent intestinal colonisation by bacterial enteropathogens if administered at the time of exposure, but have little effect on established intestinal infections.
\end{abstract}

\section{Introduction}

Diarrhoeal diseases continue to be a serious public health problem in geographic areas with inadequate water supplies and lifestyles characterised by poor sanitation and hygiene. Prevention and control programmes aimed at reducing the morbidity and mortality associated with diarrhoeal disease have made great progress with the advent of oral rehydration solutions to prevent dehydration. Because most diarrhoeal diseases are transmitted from person to person by direct or indirect contact with faeces, prevention programmes have also focused on finding ways to limit

Received 7 May 1997; accepted 27 August 1997.

Corresponding author: Dr. B. W. Petschow. exposure to enteropathogens. Another way to prevent diarrhoeal disease following unknown or unavoidable exposure to enteropathogens would be to enhance host resistance by providing dietary ingredients that would interfere with intestinal colonisation by enteropathogens. Options for enhancing host resistance include oral immunisation to enhance natural immunity, optimisation of normal host bacterial flora as an effective barrier to colonisation by ingested pathogens, or ingestion of specific antimicrobial dietary ingredients.

Previous studies have shown that certain free fatty acids and their corresponding esters have potent antibacterial and antifungal properties [1-8]. The antibacterial activity appears to be associated with 
free fatty acids (FFAs) and monoglyceride esters (MGs), but not di- or trigylcerides, is greatest for compounds that have 12 carbon atoms, and is typically greater for gram-postive than gram-negative bacteria [2, 4-6]. While the mechanism of the antimicrobial action of MGs or FFAs has not been defined, disruption of the cell membrane permeability barrier and inhibition of amino-acid uptake have been implicated $[9,10]$. Although the antimicrobial properties of FFAs and MGs in vitro are well-documented, the role of these compounds in regulating the distribution and density of bacteria of the respiratory tract, skin and gastrointestinal tract remains poorly understood.

This laboratory has been investigating naturally occurring compounds in foods that have inhibitory activity against bacterial enteropathogens. While a large body of evidence exists to support the bactericidal properties of MGs and FFAs in vitro, very little published information is available on the benefits of dietary MGs and FFAs in vivo. This led us to conduct the present studies, which were designed to evaluate the potential in-vivo benefits of oral MGs with a streptomycin-treated mouse model. This model enabled the evaluation of whether oral administration of MGs can prevent or reduce intestinal colonisation by bacterial enteropathogens.

\section{Materials and methods}

\section{Bacterial strains}

Lyophilised cultures of Vibrio cholerae (Inaba, ATCC 25870) and Escherichia coli O111 (ATCC 33780) were obtained from the American Type Culture Collection (Rockville, MD, USA). Frozen cultures of Salmonella typhi (strain ST-1) and enterotoxigenic E. coli $(\mathrm{LT}+/ \mathrm{ST}+)$ were received from $\mathrm{M}$. Neal Guentzel (University of Texas at San Antonio, San Antonio, TX, USA). A human isolate of $E$. coli $\mathrm{K} 1$ (strain $\mathrm{H}-16$ ) was kindly provided by H. V. Raff (Seattle, WA, USA). Shigella sonnei and a streptomycin-resistant strain of ETEC (2SR) were kindly provided by D. J. Hentges (Texas Tech University, Lubbock, TX, USA). All working stock cultures of bacteria were renewed monthly from frozen stocks that were maintained in Trypticase Soy Broth (TSB; BBL Laboratories) containing sterile glycerol at $-20^{\circ} \mathrm{C}$. Bacterial stock cultures were subcultured weekly on heart infusion agar and grown in TSB for $18 \mathrm{~h}$ at $37^{\circ} \mathrm{C}$ for use in bacterial killing assays. $V$. cholerae was grown in TSB without glucose (Difco Laboratories, Detroit, MI, USA).

\section{Materials}

Monocaprin (C10:0 MG), monocaprylin (C8:0 MG), monolaurin (C12:0 MG), capric acid (C10:0 FFA), caprylic acid (C8:0 FFA), lauric acid (C12:0 FFA), kanamycin and streptomycin sulphate were obtained from Sigma Chemical Co. All MG and FFA samples were soluble in water, except $\mathrm{C} 12: 0$, which was heated to $56^{\circ} \mathrm{C}$ before use to permit preparation of desired concentrations.

\section{Evaluation of bactericidal activity in vitro}

The bactericidal properties of medium-chain MG and FFA for bacterial enteropathogens was evaluated by measuring the survival of test bacteria after incubation for $4 \mathrm{~h}$ with sterile preparations of test MG or FFA. Briefly, c. $1 \times 10^{6} \mathrm{cfu}$ of washed bacterial cells were suspended in $1-\mathrm{ml}$ volumes of proteose peptone $1 \%$ culture medium (BBL Laboratories) containing test MG or FFA and incubated for $4 \mathrm{~h}$ at $37^{\circ} \mathrm{C}$. The change in number of viable bacterial cells following incubation was determined by standard plate counting procedures on TSA plates. Data were expressed as the log change in viable count $\left(\log _{10} \mathrm{cfu} / \mathrm{ml}\right)$ after incubation for $4 \mathrm{~h}$, compared to the initial bacterial count. Controls consisted of test bacterial cells incubated in proteose peptone without test MG or FA. The bactericidal activity of test MG and FFA was also evaluated in a nutritionally complete, lactose-free liquid formula diet (Lactofree, Mead Johnson and Company, Evansville, IN, USA).

\section{Animals}

Adult female CD-1 mice weighing $c$. $25 \mathrm{~g}$ were purchased from Charles River Breeding Laboratories (Portage, MI, USA) and maintained in an AAALACaccredited facility. Animals were housed 3-4 per cage in suspended wire-bottomed cages in a climatecontrolled room. Procedures in all studies involving animals were approved by a Bristol-Myers Squibb Animal Care and Use Committee and conducted in accordance with National Institutes of Health (NIH) policies and the Guide for the Care and Use of Laboratory Animals (NIH publication no. 85-23, revised 1985).

\section{Prevention of bacterial colonisation by $M G$ in vivo}

The ability of dietary MG to prevent bacterial colonisation in vivo was determined by measuring the change in recovery of a standard challenge dose of $V$. cholerae or ETEC cells from gastrointestinal tracts of mice. Adult mice were maintained on a lactose-free infant formula (Lactofree) at twice normal strength during a 7-day acclimatisation period. The following day, $V$. cholerae or ETEC cells (early log phase) were washed with $0.01 \mathrm{M}$ phosphate-buffered saline (PBS), suspended to give $c .4 \times 10^{7} \mathrm{cfu} / \mathrm{ml}$ in the appropriate test diet and administered immediately to fasted mice by intragastric gavage (concurrent administration). Streptomycin-resistant strains of $V$. cholerae and ETEC were used to allow differentiation of the test bacteria 
from normal intestinal bacterial flora. Individual animals received c. $1 \times 10^{6} \mathrm{cfu}$ of $V$. cholerae or ETEC in $0.2 \mathrm{ml}$ of test diet. Survival of the bacterial inoculum following concurrent administration with test MG was determined $1 \mathrm{~h}$ after challenge by counting the total number of viable $V$. cholerae or ETEC cells recovered from homogenates of stomach, small intestine and caecum on TSA or MacConkey agar plates containing $1 \mathrm{mg} / \mathrm{ml}$ streptomycin (STR). Additional studies showed that homogenates of stomach, small intestine or caecal tissues from control mice were negative for STR-resistant bacteria from the normal intestinal flora.

\section{Impact of $M G$ on previously colonised bacterial enteropathogens}

The ability of dietary MG to clear previously established intestinal enteropathogens in vivo was assessed by measuring the changes in number of viable $V$. cholerae or ETEC in the small intestine and caecum following administration of $\mathrm{MG}$ in the diet. Adult mice were maintained on a liquid diet (Lactofree) containing STR at $2 \mathrm{mg} / \mathrm{ml}$ during a 5-day acclimation period. The next day (day 0 ), $V$. cholerae or ETEC cells (early log phase cultures) were washed with $0.01 \mathrm{M}$ PBS, suspended to give $c .1 \times 10^{7} \mathrm{cfu} / \mathrm{ml}$ in liquid diet and administered to fasted mice by intragastric gavage $(0.2 \mathrm{ml} / \mathrm{animal})$. Animals were returned to cages and given liquid diet containing STR alone or in combination with test MG for up to 4 days. Test groups received Lactofree containing test MG (or kanamycin as control) starting $24 \mathrm{~h}$ before (day -1), $1 \mathrm{~h}$ after (day 0) or 2 days after (day 2) challenge with $V$. cholerae or ETEC. Feeding of test diets was continued until day 4, when the number of viable $V$. cholerae or ETEC bacteria present in tissue homogenates of small intestine and caecum were determined by plating on TSA or MacConkey agar plates containing STR $1 \mathrm{mg} / \mathrm{ml}$. Streptomycin-resistant strains of $V$. cholerae or ETEC were used to colonise mice to facilitate differentiation of test bacteria from normal intestinal bacterial flora. Streptomycin was administered in liquid diet instead of drinking water to normalise the volume of STR consumed, as mice show variable water consumption patterns. Previous studies showed that administration of liquid diet containing streptomycin caused no changes in physical conditions or activity of test mice other than a slight softening of stool.

\section{Statistical methods}

Treatment effects on in-vitro inactivation of bacterial cultures were analysed by one-way analysis of variance and Tukey's multiple comparison procedure with log transformed data (SAS/LAB PC version 6.08). Differences were deemed statistically significant when the probability value was $\leqslant 0.05$.

\section{Results}

\section{Bactericidal activity of $M G$ and FFA in vitro}

The bactericidal activity of several medium-chain MG and FFA was tested in vitro against various bacterial enteropathogens. Medium-chain MG (C8:0, C10:0, $\mathrm{C} 12: 0)$ were consistently more bactericidal than the corresponding FFA for bacterial enteropathogens when tested in a proteose peptone medium (Table 1). All species tested were sensitive to C10:0 MG (monocaprin) $0.25 \mathrm{~g} / \mathrm{L}$ and $1.25 \mathrm{~g} / \mathrm{L}$ C8:0 MG (monocaprylin), showing $\geqslant 100$-fold reductions in numbers of viable cells $(p<0.05)$ after incubation for $4 \mathrm{~h}$ in vitro. In contrast, controls (test bacterial cultures without $\mathrm{MG}$ or FFA) showed 6-350-fold increases in viable counts $\left(0.76-2.54 \log _{10} \mathrm{cfu} / \mathrm{ml}\right)$ after incubation under identical conditions. Monolaurin (C12:0 MG) was also bactericidal for $S$. typhi, Sh. sonnei and $V$. cholerae $(\mathrm{p}<0.05)$, but not $E$. coli. None of the test bacteria was affected by incubation with C8:0 FFA or C10:0

Table 1. In-vitro bactericidal activity of medium-chain MGs and FFAs for bacterial enteropathogens

\begin{tabular}{|c|c|c|c|c|c|c|c|}
\hline \multirow[b]{2}{*}{ MG or FFA } & \multirow{2}{*}{$\begin{array}{l}\text { Concentration } \\
(\mathrm{g} / \mathrm{L})\end{array}$} & \multicolumn{6}{|c|}{ Change in number of viable bacteria $\left(\log _{10}(\mathrm{SD}) \mathrm{cfu} / \mathrm{ml}\right)^{*}$} \\
\hline & & S. typhi & V. cholerae & E. coli $(\mathrm{ET})$ & E. coli $(\mathrm{EP})$ & E. $\operatorname{coli}(\mathrm{K} 1)$ & Sh. sonnei \\
\hline Control & - & $0.16(0.06)$ & $0.76(0.09)$ & $2.54(0.09)$ & $1.48(0.57)$ & $2.38(0.13)$ & $0.99(0.25)$ \\
\hline \multirow[t]{2}{*}{ C8:0 MG (monocaprylin) } & 0.25 & $-0.09(0.15)$ & $0.09(0.27)$ & $\mathrm{NT}$ & $1.70(0.11)$ & $2.06(0.32)$ & $0.66(0.30)$ \\
\hline & 1.25 & $-2.90(0.33)^{\dagger}$ & $-3.41(0.62)^{\dagger}$ & $-1.78(0.37)^{\dagger}$ & $-2.64(0.68)^{\dagger}$ & $-2.38(0.36)^{\dagger}$ & $-2.36(0.46)^{\dagger}$ \\
\hline \multirow[t]{2}{*}{ C10:0 MG (monocaprin) } & 0.25 & $-4.97(0.18)^{\dagger}$ & $-4.52(0.62)^{\dagger}$ & $\mathrm{NT}$ & $-2.63(0.85)^{\dagger}$ & $-2.62(0.70)^{\dagger}$ & $-4.06(0.12)^{\dagger}$ \\
\hline & 1.25 & NT. & NT & $-2.09(1.79)^{\dagger}$ & $-3.42(0.98)^{\dagger}$ & NT & $-4.08(0.10)^{\dagger}$ \\
\hline \multirow[t]{2}{*}{ C12:0 MG (monolaurin) } & 0.25 & $-2.42(0.37)^{\dagger}$ & $-4.57(0.62)^{\dagger}$ & NT & NT & NT & $-3.03(0.10)^{\dagger}$ \\
\hline & 1.25 & $\mathrm{NT}$ & NT & $2.32(0.03)$ & $1.11(0.37)$ & $1.33(0.12)$ & $-3.08(0.06)^{\dagger}$ \\
\hline \multirow[t]{2}{*}{ C8:0 FFA (caprylic acid) } & 0.25 & $0.47(0.07)$ & $0.78(0.28)$ & NT & NT & NT & NT \\
\hline & 1.25 & $-0.36(0.28)$ & $0.58(0.39)$ & $2.18(0.34)$ & $1.50(0.06)$ & $2.11(0.08)$ & $0.46(0.62)$ \\
\hline \multirow[t]{2}{*}{ C10:0 FFA (capric acid) } & 0.25 & $0.49(0.05)$ & $0.57(0.22)$ & $2.51(0.12)$ & $2.27(0.30)$ & $2.42(0.07)$ & NT \\
\hline & 1.25 & $0.02(0.06)$ & $0.98(0.19)$ & $2.47(0.02)$ & $0.49(0.14)$ & $2.58(0.08)$ & $0.40(0.44)$ \\
\hline \multirow[t]{2}{*}{ C12:0 FFA (lauric acid) } & 0.25 & $-2.81(0.06)^{\dagger}$ & $-4.92(0.11)^{\dagger}$ & $\mathrm{NT}$ & NT & NT & $-1.03(0.15)^{\dagger}$ \\
\hline & 1.25 & NT & NT & $2.09(0.26)$ & $1.55(0.12)$ & $2.07(0.15)$ & $-0.54(0.10)$ \\
\hline
\end{tabular}

NT, not tested.

${ }^{*}$ Represents the mean increase or decrease in $\log _{10}$ (SD) number of viable cells following incubation for $4 \mathrm{~h}$ with the indicated monoglyceride (MG) or fatty acid (FFA) in proteose peptone growth medium. Initial inoculum for all test organisms was $(1-9) \times 10^{5} \mathrm{cfu} / \mathrm{ml}$. Results are from at least duplicate determinations.

Different from control $(\mathrm{p}<0.05)$. 
FFA at concentrations as high as $1.25 \mathrm{~g} / \mathrm{L}$. Lauric acid (C12:0 FFA) was similar to monolaurin (C12:0 MG) in bactericidal activity, showing effective killing of $S$. typhi, Sh. sonnei and $V$. cholerae $(\mathrm{p}<0.05)$, but not $E$. coli.

\section{Bactericidal activity of $M G$ and FFA in liquid diet}

Higher concentrations of medium-chain MGs were required to show bactericidal activity for $V$. cholerae and ETEC when incubated in a high protein, liquid diet (Table 2). Both $\mathrm{C} 8: 0 \mathrm{MG}$ and $\mathrm{C10:0} \mathrm{MG}$ were bactericidal for $V$. cholerae in liquid diets at $2.5 \mathrm{~g} / \mathrm{L}$ $(\mathrm{p}<0.05)$. However, the activity of $\mathrm{C12:0} \mathrm{MG}$ and FFA was considerably lower in liquid diet than in proteose peptone, requiring at least four-fold higher levels $(10 \mathrm{~g} / \mathrm{L})$ to achieve $\geqslant 100$-fold reductions in

Table 2. In-vitro bactericidal activity of medium-chain MGs and FFAs for $V$. cholerae and enterotoxigenic $E$. coli (ETEC) in a high protein formula diet

\begin{tabular}{|c|c|c|c|}
\hline \multirow[b]{2}{*}{$\mathrm{MG}$ or FFA } & \multirow{2}{*}{$\begin{array}{c}\text { Concentration } \\
(\mathrm{g} / \mathrm{L})\end{array}$} & \multicolumn{2}{|c|}{ Change in number of viable bacteria ${ }^{*}$} \\
\hline & & $V$. cholerae & ETEC \\
\hline Control & - & $0.23(0.15)$ & $2.78(0.33)$ \\
\hline \multirow[t]{3}{*}{$\mathrm{C} 8: 0 \mathrm{MG}$} & 2.5 & $-2.37(0.85)^{\dagger}$ & $2.09(0.04)$ \\
\hline & 5.0 & $-2.69(0.38)^{\dagger}$ & $-3.79(0.37)^{\dagger}$ \\
\hline & 10.0 & $-3.36(0.85)^{\dagger}$ & $-4.29(0.03)^{\dagger}$ \\
\hline \multirow[t]{3}{*}{$\mathrm{C} 10: 0 \mathrm{MG}$} & 2.5 & $-2.69(0.38)^{\dagger}$ & NT \\
\hline & 5.0 & $-2.69(0.38)$ & $2.22(0.01)$ \\
\hline & 10.0 & $-3.69(0.38)^{\dagger}$ & $2.31(0.09)$ \\
\hline \multirow[t]{3}{*}{$\mathrm{C} 12: 0 \mathrm{MG}$} & 2.5 & $-0.08(0.30)$ & NT \\
\hline & 5.0 & $-0.16(0.14)$ & $2.40(0.10)$ \\
\hline & 10.0 & $-0.61(0.57)$ & $2.44(0.13)$ \\
\hline \multirow[t]{3}{*}{ C12:0 FFA } & 2.5 & $-0.12(0.18)$ & $\mathrm{Nt}$ \\
\hline & 5.0 & $-0.38(0.61)$ & $2.48(0.19)$ \\
\hline & 10.0 & $-3.13(0.06)^{\dagger}$ & $2.14(0.12)$ \\
\hline
\end{tabular}

NT, not tested.

* Represents the mean increase or decrease in $\log _{10}$ (SD) number of viable cells following a $4 \mathrm{~h}$ incubation period with the indicated $\mathrm{MG}$ or FFA in Lactofree infant formula. Initial inoculum of test bacteria was c. $1.0 \times 10^{5} \mathrm{cfu} / \mathrm{ml}$. Results are of at least duplicate determinations.

'Significantly different from control $(\mathrm{p}<0.05)$. viable counts of $V$. cholerae. While C8:0 MG showed bactericidal activity for ETEC at $5.0 \mathrm{~g} / \mathrm{L}$ in liquid diet $(p<0.05)$, no killing on ETEC was observed with C10:0 MG, C12:0 MG or C12:0 FFA in liquid diets at concentrations as high as $10 \mathrm{~g} / \mathrm{L}$.

\section{Prevention of bacterial colonisation in vivo by oral $M G$}

The ability of MG to prevent intestinal colonisation with bacterial enteropathogens was evaluated by determining the recovery of $V$. cholerae or ETEC from intestinal tissues of STR-treated mice $1 \mathrm{~h}$ after intragastric challenge with test bacteria alone or in combination with test MG. When control mice were challenged intragastrically with $3.0 \times 10^{6} \mathrm{cfu}$ of $V$. cholerae, c. $3.6 \times 10^{5}$ cfu $\left(5.56 \log _{10}\right)$ were recovered after $1 \mathrm{~h}$ (Table 3 ). No reduction was observed in the number of viable $V$. cholerae recovered from intestinal tissues following concurrent administration of test bacteria with C10:0 MG at 0.25 or $1.25 \mathrm{~g} / \mathrm{L}$. However, when mice were given $V$. cholerae concurrently with C10:0 MG at $2.5 \mathrm{~g} / \mathrm{L}$, no viable $V$. cholerae were recovered from the stomach, small intestine or caecum of challenged mice $(\mathrm{p}<0.05)$. C12:0 at $2.5 \mathrm{~g} / \mathrm{L}$ had no effect on $V$. cholerae colonisation. Concurrent administration of $V$. cholerae with a control antibiotic (kanamycin, $0.1 \mathrm{mg} / \mathrm{ml}$ ) decreased the number of viable $V$. cholerae recovered from the intestinal tract of mice; no $V$. cholerae were recovered from the intestinal tract of two of eight mice, while recovery of $V$. cholerae in the remaining mice was $c$. 65 -fold lower than in control mice receiving $V$. cholerae alone.

Control mice challenged with $3.0 \times 10^{6} \mathrm{cfu}$ of ETEC showed a mean recovery of viable ETEC of $1.5 \times 10^{6} \mathrm{cfu}\left(6.19 \log _{10}\right)$ after $1 \mathrm{~h}$ (Table 3). In contrast to results with $V$. cholerae, no reduction was observed in the number of viable ETEC recovered from stomach, small intestine and caecum of mice after concurrent administration with $\mathrm{C} 10: 0 \mathrm{MG}$ at concentrations as high as $5.0 \mathrm{~g} / \mathrm{L}$.

Table 3. Survival of $V$. cholerae and enterotoxigenic E. coli (ETEC) in adult mice following oral administration of medium-chain MGs

\begin{tabular}{|c|c|c|c|}
\hline \multirow{2}{*}{$\begin{array}{l}\text { Test } \\
\text { additive }\end{array}$} & \multirow{2}{*}{$\begin{array}{l}\text { Concentration } \\
(\mathrm{g} / \mathrm{L})\end{array}$} & \multicolumn{2}{|c|}{ Viable bacteria $\left(\log _{10}(\mathrm{SD}) \mathrm{cfu}\right)$ recovered from intestines* } \\
\hline & & V. cholerae Number positive/total & ETEC Number positive/total \\
\hline Control & - & $5.56(0.35) 8 / 8$ & $6.19(0.20) 8 / 8$ \\
\hline $\mathrm{C} 10: 0 \mathrm{MG}$ & 0.25 & $5.93(0.25) 8 / 8$ & NT \\
\hline $\mathrm{C} 10: 0 \mathrm{MG}$ & 1.25 & $5.14(0.24) 8 / 8$ & NT \\
\hline $\mathrm{C} 10: 0 \mathrm{MG}$ & 2.50 & $<3.0^{\dagger+} 0 / 8^{\ddagger}$ & $5.37(0.23) 8 / 8$ \\
\hline $\mathrm{C} 10: 0 \mathrm{MG}$ & 5.00 & NT & $5.10(0.40) 10 / 10$ \\
\hline $\mathrm{C} 12: 0 \mathrm{MG}$ & 2.50 & $5.58(0.50) 8 / 8$ & NT \\
\hline Kanamycin & 0.10 & $3.73(0.25)^{\ddagger} 6 / 8$ & NT \\
\hline
\end{tabular}




\section{Effect of dietary $M G$ on pre-existing bacterial pathogens in vivo}

An in-vivo therapeutic benefit of oral MG against bacterial enteropathogens was evaluated by monitoring the number of viable $V$. cholerae or ETEC present in the caecum and associated with ileal tissue in mice that were challenged with test bacteria and fed diets containing MG. Mice given $3 \times 10^{5}$ cfu of ETEC by intragastric gavage $(\mathrm{n}=10)$ showed stable intestinal colonisation with ETEC by day 4 (Table 4). The mean numbers of viable ETEC ( $\log _{10} \mathrm{cfu} / \mathrm{g}$ of tissue) found in the caecum and associated with ileal tissue of STRtreated mice 4 days after challenge were 8.39 and 5.71, respectively. Daily administration of C10:0 MG in the diet at $5.0 \mathrm{~g} / \mathrm{L}$ starting 1 day before, $1 \mathrm{~h}$ after or 1 day after challenge with ETEC did not reduce the numbers of ETEC in the caecum or ileum at day 4 (Table 5). Daily adminstration of kanamycin $(0.1 \mathrm{~g} / \mathrm{L})$ in liquid diet starting the same day as bacterial challenge reduced both the incidence ( 4 of 10) and numbers of ETEC found in the caecum and associated with the ileum $(p<0.05)$, compared to control mice fed diet alone.

The mean number of viable $V$. cholerae $\left(\log _{10} \mathrm{cfu} / \mathrm{g}\right.$ tissue) found in the caecum and associated with ileal tissue 4 days after intragastric challenge of control STR-treated mice was 8.14 and 4.51 , respectively.
Concurrent administration of $V$. cholerae and C10:0 MG at $2.5 \mathrm{~g} / \mathrm{L}$ resulted in lower incidence of colonisation and overall numbers of $V$. cholerae in the intestine by day 4 than in control mice receiving $V$. cholerae alone; no $V$. cholerae were recovered from caecum or ileum of 9 of 10 mice $(p<0.05)$, while mean recovery of $V$. cholerae in the only colonised mouse was c. 4000-fold lower than in control mice receiving $V$. cholerae alone. Daily administration of $\mathrm{C} 10: 0 \mathrm{MG}$ at $5.0 \mathrm{~g} / \mathrm{L}$ in the diet starting 1 day before, the same day or 1 day after bacterial challenge did not reduce the incidence or level of $V$. cholerae in the caecum or ileum by day 4 .

\section{Discussion}

The majority of investigations into the antibacterial properties of lipids have studied the inhibitory properties of saturated and mono-unsaturated fatty acids with less focus on the activity of monoacylglycerol esters of fatty acids. Several of these studies have reported that gram-positive bacteria show greater sensitivity in vitro to FFAs and MGs than gram-negative bacteria $[2,6]$. The present study found that medium-chain MGs are highly bactericidal in vitro for several different types of gram-negative bacterial enteropathogens. Because the results of earlier studies with fatty acids and $E$. coli have not been consistent, this study evaluated the

Table 4. Impact of oral administration of monocaprin (C10:0 MG) on intestinal levels of enterotoxigenic $E$. coli (ETEC) in adult mice starting 1 day before, the same day, or 2 days after bacterial challenge

\begin{tabular}{|c|c|c|c|c|c|}
\hline \multirow[b]{2}{*}{ Treatment* } & \multirow[b]{2}{*}{ Day treatment started } & \multirow[b]{2}{*}{ Day treatment ended } & \multicolumn{2}{|c|}{ Recovery of ETEC $\left(\log _{10}(\text { SEM) } \mathrm{cfu} / \mathrm{g})^{\dagger}\right.$} & \multirow[b]{2}{*}{ Number positive/total } \\
\hline & & & Ileal mucosa & Caecum & \\
\hline Control & - & 4 & $5.71(0.69)$ & $8.39(0.47)$ & $10 / 10$ \\
\hline $\mathrm{C} 10: 0 \mathrm{MG}$ & -1 & 4 & $6.23(0.62)$ & $8.50(0.21)$ & $10 / 10$ \\
\hline $\mathrm{C} 10: 0 \mathrm{MG}$ & 0 & 4 & $5.72(0.60)$ & $8.50(0.14)$ & $10 / 10$ \\
\hline $\mathrm{C} 10: 0 \mathrm{MG}$ & 2 & 4 & $6.14(0.39)$ & $8.63(0.26)$ & $10 / 10$ \\
\hline Kanamycin & 0 & 4 & $4.14(1.55)^{\ddagger}$ & $4.74(0.11)^{\ddagger}$ & $4 / 10^{\ddagger}$ \\
\hline
\end{tabular}

* Animals were fed liquid diet containing streptomycin (STR) from day -5 to initiation of treatment of same diet containing STR and monocaprin $(\mathrm{C} 10: 0 \mathrm{MG}, 5 \mathrm{~g} / \mathrm{L})$ or kanamycin $(0.1 \mathrm{~g} / \mathrm{L})$ starting 1 day before, the same day, or 2 days after bacterial challenge. Mice were challenged intragastrically on day 0 with $c .3 \times 10^{5}$ cfu of ETEC in liquid diet and killed on day 4 .

${ }^{\dagger}$ Represents the mean $\log _{10}$ (SEM) number of viable ETEC recovered from ileal mucosal tissue or caecum 4 days after intragastric challenge. ${ }^{\ddagger}$ Different from control mice fed diet containing STR only $(\mathrm{p}<0.05)$.

Table 5. Impact of oral administration of monocaprin (C10:0 MG) on intestinal levels of $V$. cholerae in adult mice when administered 1 day before, the same day, or 2 days after bacterial challenge

\begin{tabular}{|c|c|c|c|c|c|}
\hline \multirow[b]{2}{*}{ Treatment $^{*}(\mathrm{~g} / \mathrm{L})$} & \multirow[b]{2}{*}{ Day treatment started } & \multirow[b]{2}{*}{ Day treatment ended } & \multicolumn{2}{|c|}{ Recovery of $V$. cholerae $\left(\log _{10}(\mathrm{SEM}) \mathrm{cfu} / \mathrm{g}\right)^{\dagger}$} & \multirow[b]{2}{*}{ Number positive total } \\
\hline & & & Ileal tissue & Caecum & \\
\hline None & - & 4 & $4.51(0.59)$ & $8.14(0.22)$ & $9 / 10$ \\
\hline $\mathrm{C} 10: 0 \mathrm{MG}(2.5 \mathrm{~g} / \mathrm{L})$ & Concurrent & 4 & ND & $4.54(0.00)$ & $1 / 10^{\ddagger}$ \\
\hline $\mathrm{C} 10: 0 \mathrm{MG}(5 \mathrm{~g} / \mathrm{L})$ & -1 & 4 & $3.98(0.66)$ & $8.01(0.15)$ & $7 / 10$ \\
\hline $\mathrm{C} 10: 0 \mathrm{MG}(5 \mathrm{~g} / \mathrm{L})$ & 0 & 4 & $4.57(0.57)$ & $7.86(0.64)$ & $10 / 10$ \\
\hline $\mathrm{C} 10: 0 \mathrm{MG}(5 \mathrm{~g} / \mathrm{L})$ & 2 & 4 & $4.87(0.59)$ & $8.43(0.12)$ & $5 / 10^{\ddagger}$ \\
\hline
\end{tabular}

ND, none detected

* Animals were fed liquid diet containing streptomycin (STR) for 5 days, challenged with $V$. cholerae in liquid diet alone or concurrently with

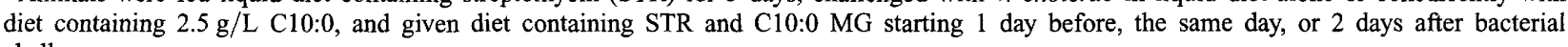
challenge.

${ }^{\dagger}$ Represents the mean $\log _{10}(\mathrm{SEM})$ number of viable $V$. cholerae cells recovered from ileal mucosal tissue or caecum by day 4 after orogastric challenge.

${ }^{\ddagger}$ Different from control mice fed diet containing STR only $(\mathrm{p}<0.05)$. 
bactericidal properties of FFA and $M G$ against representatives of several types of pathogenic $E$. coli, including enterotoxigenic $E$. coli, enteropathogenic $E$. coli and $E$. coli serotype $\mathrm{K} 1$ implicated in neonatal sepsis. The results indicate that strains of $E$. coli respond uniformly to the antibacterial activity of MG. All three strains of $E$. coli tested were sensitive to C10:0 MG and C8:0 MG and resistant to both the C12:0 MG and C12:0 FFA, despite high bactericidal activity of the C12:0 compounds for other gramnegative bacteria.

The results with gram-negative bacteria differ from those of Conley et al. [2] who reported that several monoglycerol esters of medium-chain fatty acids were bactericidal for gram-positive bacteria but without activity for a panel of gram-negative bacteria, including strains of Proteus, E. coli, Klebsiella spp., S. typhimurium and Serratia spp. Kato et al. [6] also reported no killing of Pseudomonas aeruginosa or $E$. coli with monolaurin. These contradictory results might be explained by differences in test strains, media, or assay conditions. It is also important to recognise that medium-chain MGs and FFAs vary in their aqueous solubility, which might explain disparate results. Monoglycerides and free fatty acids must be sufficiently water soluble to reach necessary concentrations in the aqueous phase and ensure adequate contact with bacterial surfaces.

When mice were challenged in this study with $V$. cholerae concurrently with MG to evaluate prophylactic benefits of bacterial lipids against enteric bacterial infections, viable $V$. cholerae could not be recovered from any of the test mice $1 \mathrm{~h}$ after they received the bacterial inoculum with $\mathrm{C10:0} \mathrm{MG}$ at $2.5 \mathrm{~g} / \mathrm{L}$. This suggests that relatively brief exposure of $V$. cholerae to C10:0 MG during gastric transit was sufficient to inactivate the bacterial inoculum. Lower concentrations of $\mathrm{C} 10: 0 \mathrm{MG}$ were ineffective at reducing either the number of animals that were positive for $V$. cholerae or the number of viable bacteria remaining from the challenge inoculum. Because it is accepted that fat digestion begins in the stomach $[11,12]$ and that medium-chain FFA may be absorbed by the gastric mucosa [13, 14], it is possible that a bactericidal MG such as monocaprin may become inactive during gastric transit due to conversion to inactive fatty acid (capric acid) or absorption through the gastric mucosa. The study also tested the prophylactic benefits of dietary monolaurin (C12:0 MG), as gastric digestion of monolaurin would generate C12:0 FFA (lauric acid) which was also bactericidal for $V$. cholerae (Table 1). However, it was found that concurrent administration had no effect on either the incidence of isolation of vibrios or the total number of viable vibrios recovered from the intestinal tract of test mice. However, the lack of activity by C12:0 MG appeared to be due to a greater loss of bactericidal activity when mixed with the Lactofree diet compared to $\mathrm{C} 8: 0$ and $\mathrm{C} 10: 0 \mathrm{MG}$. Concurrent administration of ETEC with C10:0 MG at levels as high as $5 \mathrm{~g} / \mathrm{L}$ also had no effect on the viability of the challenge bacterial inoculum in test mice. This might be explained by the finding that $\mathrm{MG}$ that were bactericidal for $V$. cholerae and ETEC in proteose peptone were much less bactericidal in the Lactofree diet. Previous studies have shown that certain nutrients in relatively high concentrations could alter the availability of MG and FFA and, therefore, decrease their bactericidal properties $[3,6,15-17]$. Such interaction of $\mathrm{MG}$ with dietary components might explain the observation that $\mathrm{C} 10: 0 \mathrm{MG}$ was unable to inactivate ETEC bacterial inoculum when administered concurrently. While it might be possible to add sufficient amounts of MG or FFA to dietary products to ensure bactericidal activity in the presence of antagonistic food ingredients, high levels may be undesirable because of adverse effects on organoleptic and functional qualities $[18,19]$.

The study also evaluated the therapeutic benefits of orally administered C10:0 MG against enterotoxigenic $E$. coli and $V$. cholerae, with the streptomycin-treated mouse model of intestinal colonisation. Administration of kanamycin in the daily diet for 4 days following bacterial challenge caused a significant reduction both in the number of animals colonised and the numbers of marker bacteria found in colonised animals, indicating that this model was valid for evaluating therapeutic efficacy of orally administered bactericidal compounds. When mice were challenged with $V$. cholerae and given C10:0 MG concurrently and maintained on Lactofree diet for 4 days, no viable $V$. cholerae could be recovered from ileal tissue or the caecum in 9 of 10 mice. The single animal that was positive for $V$. cholerae had very low numbers of vibrios in the caecum. This result confirms that the number of $V$. cholerae that may have survived concurrent administration with C10:0 MG (Table 2) were not sufficient to allow subsequent outgrowth and colonisation of the intestinal tract during a 4-day period. However, challenging mice with $V$. cholerae or ETEC and providing C10:0 MG in the diet starting 1 day before, $1 \mathrm{~h}$ after, or $24 \mathrm{~h}$ after bacterial challenge did not clear or reduce the numbers of marker bacteria in the intestinal tract by day 4 . These results indicate that therapeutic administration of bactericidal MG has little effect on levels of bacterial enteropathogens that have already become established in the intestinal tract. It is possible that digestion or absorption of the C10:0 MG and FFA during transit through the duodenum and proximal jejunum [11] may have resulted in a decrease in the amount of bactericidal MG available by the time it reached the ileum and caecum where the majority of the $V$. cholerae and ETEC cells reside.

In conclusion, this study found that administration of C10:0 MG to mice at the time of exposure to a bacterial pathogen prevents intestinal colonisation by 
killing the majority of bacteria in the challenge inoculum. Oral administration of C10:0 MG to mice that were previously colonised by bacterial enteropathogens had no effect on intestinal levels of the challenge organism, which may be related to digestion or absorption of the dietary MG during intestinal transit. Collectively, these results suggest that oral administration of bactericidal MG or FFA may provide protection against enteric bacterial disease by preventing intestinal colonisation before it becomes established, but such compounds may have limited therapeutic impact on previously established intestinal infections by bacterial pathogens.

We thank Kristi Covalciuc and Karen Wojciechowski for their technical contributions and Nancy West for her help in preparation of the manuscript.

\section{References}

1. Bayliss M. Effect of the chemical constitution of soaps upon their germicidal properties. J Bacteriol 1936; 31: 489-504.

2. Conley AJ, Kabara JJ. Antimicrobial action of esters of polyhydric alcohols. Antimicrob Agents Chemother 1973; 4: $501-506$.

3. Glassman HN. Surface-active agents and their application in bacteriology. Bacteriol Rev 1949; 12: 105-148.

4. Kabara JJ, Swieczkowski DM, Conley AJ, Truant JP. Fatty acids and derivatives as antimicrobial agents. Antimicrob Agents Chemother. 1972; 2: 23-28.

5. Kabara JJ. Fatty acids and derivatives as antimicrobial agents In: Kabara JJ (ed) The pharmacological effects of lipids. Champaign, IL, American Oil Chemist Society. 1978; 1-14.

6. Kato N, Shibasaki I. Comparison of antimicrobial activities of fatty acids and their esters. $J$ Ferment Technol 1975; 53: $793-801$.

7. Knapp HR, Melly MA. Bactericidal effects of polyunsaturated fatty acids. $J$ Infect Dis 1986; 154: 84-94.

8. Nieman C. Influence of trace amounts of fatty acids on the growth of microorganisms. Bacteriol Rev 1954; 18: 147-163.

9. Kato N, Shibasaki I. Combined effect of citric and polyphosphoric acids on the antibacterial activity of monoglycerides. $J$ Antibact Antifungal Agents 1976; 4: 254-261.

10. Shibasaki I, Kato N. Combined effects on antibacterial activity of fatty acids and their esters against gram-negative bacteria. In: Kabara JJ (ed) The phamacological effects of lipids. Champaign, IL, American Oil Chemist Society. 1978: 15-24.

11. Borgstrom B, Dahlqvist A, Lundh G, Sjovall J. Studies of intestinal digestion and absorption in the human. $J$ Clin Invest 1957; 36: 1521-36.

12. Eastwood MA, Hamilton D. Fatty acids in the lumen of the small intestine of man following a lipid-containing meal. Scand J Gastroenterol 1970; 5: 225-230.

13. Faber J, Goldstein R, Blondheim O, Stankiewicz $\mathrm{H}$ et al. Absorption of medium-chain triglycerides in the stomach of the human infant. J Pediatr Gastroenterol Nutr 1988; 7: $189-195$

14. Hamosh M, Bitman J, Liao TH et al. Gastric lipolysis and fat absorption in the preterm infant: effect of medium-chain triglyceride or long-chain triglyceride containing formula. Pediatrics 1989; 83: 86-92.

15. Dubos, RJ. The effect of lipids and serum albumin on bacterial growth. J Exp Med 1947; 85: 9-22.

16. Pollock MR. The effects of long-chain fatty acids on the growth of Haemophilus pertussis and other organisms. Symp Soc Exp Biol 1949; 3: 193-216.

17. Wynne ES, Foster JW. Studies on the effects of $C_{18}$ unsaturated fatty acids on growth and respiration of Micrococcus pyogenes var. aureus. J Infect Dis 1950; 86: 33-37.

18. Al-Shabibi MMA, Langer EH, Tobias J, Tuckey SL. Effect of added fatty acids on the flavor of milk. $J$ Dairy Sci 1964; 47: 295-297.

19. Kinter JA, Day EA. Major free fatty acids in milk. $J$ Dairy $S c i$ 1965; 48: $1575-1581$. 